\title{
担癌状態で長期生存し得た鼻腔悪性黒色腫例
}

\author{
田浦 晶子1) ・ 伊藤 壽一1) 大大田 耕造2) 藤田 修治 ${ }^{2}$ \\ 遠藤 剛(2) ・ 雑賀 興慶 $32 \cdot$ 芥田 敬三4)
}

\section{Long-term Survival in a Case of Malignant Melanoma of the Nose}

\author{
Akiko Taura and Juichi Ito \\ (Kyoto University) \\ Kohzo Ohta, Shuji Fujita, Tsuyoshi Endo, Tatsuyoshi Saiga and Keizo Akutada \\ (Otsu Red Cross Hospital)
}

\begin{abstract}
A 64-year-old female exhibiting a malignant melanoma of the nose received radiotherapy in 1979. In 1984, ileal metastasis occured and was resected. In 1992, pelvic bone metastasis was discovered and she received radiotherapy. In 1998, a recurrent tumor was discovered in the primary site (left nasal cavity).

In contrast to some reports that sinonasal malignant melanoma is resistant to radiotherapy, in this case, radiotherapy seems to have been effective. She received only radiotherapy and had distant metastasis, but her long-term survival rate was good. The prognosis of sinonasal malignant melanoma is very poor, but a few cases of prolonged survival have been reported. Malignant melanoma is divided into two types, fulminant and nonfulminant, and the latter has a good prognosis. In theory there should be immunological differences between them, but at present the differences have not been clearly identified.
\end{abstract}

Key words : malignant melanoma, radiotherapy, long-term survival

\section{はじめに}

鼻・副鼻腔の悪性黒色腫は悪性度が高くきわめて予後 不良な疾患として知られている．近年との增加傾向を指 摘されている1) ともかかわらず, いまだ確立された治療 法がなく，この15年間に拈いても生存率の改善も認めら れていない2)。乙かし, 悪性黒色腫のなかにはまれに長 期にわたって生存する症例が以前より報告されてい る3) 5).

今回われわれも担癌状態ではあるものの発症より約 20 年間と長期にわたって生存し得た症例を経験したので, その治療法执よびその原因について若干の考察を加兄て 報告する。

\section{症 例}

症例 : 64歳, 女性.

主訴 : 左鼻出血.

現病歴 : 昭和53年に左鼻出血があり近院を受診した. 鼻茸を指摘され生検を受けるも悪性所見を認めず経過観 察されていた。翌54年, 再度の生検で悪性黒色腫と診断 されたため大津赤十字病院耳鼻咽喉科を紹介された。初 診時, 左鼻腔内はポリープで充満し単純 X線像では左鼻 腔内に腫瘍陰影を認めた (図 1 ).

既往歷・家族歷 : 特記すべさことなし。

治療経過(図 2 )：昭和54年 4 月より鼻腔にコバルト $6000 \mathrm{rad}$ を照射したところ，鼻出血は止血し腫瘍も消失
1) 京都大学大学院医学研究科 感覚運動系病態学講座 耳鼻咽喉科 - 頭頸部外科学

3）大津赤十字病院病理部
2）大津赤十字病院耳鼻咽喉科

4）大津赤十字病院放射線科 


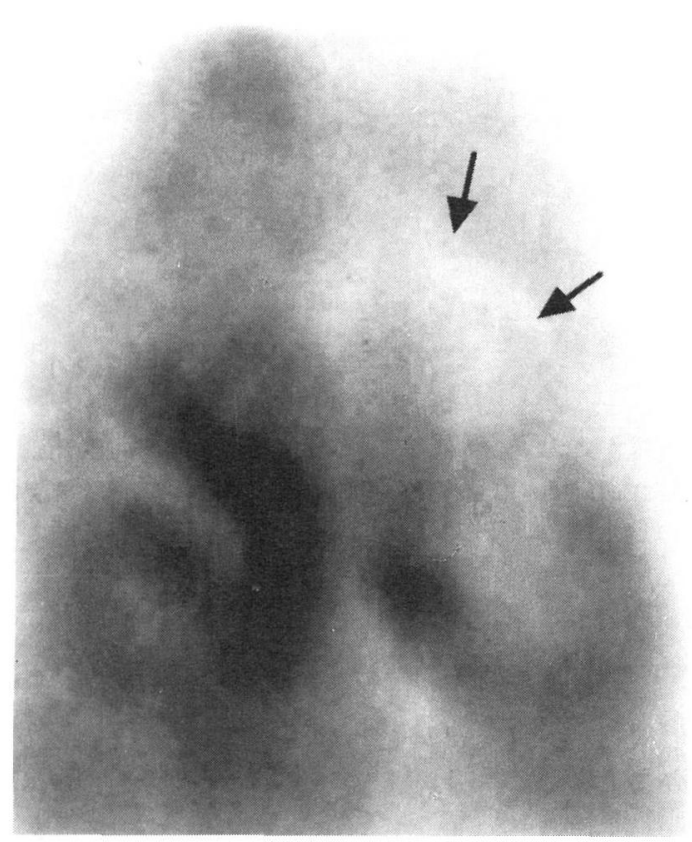

図 1 鼻X線像

左鼻腔に腫瘍陰影を認める(矢印).

した。しかし，昭和59年には回腸に転移を認めたため回 腸部分切除を施行. 回腸には黒色の色素沈着を伴った腫 瘍を認めた（図 3 ). さらに平成 3 年には左股関節部に疼 痛が出現した。左恥骨から坐骨にかけて骨転移を認めた ため同部に LINAC $45 \mathrm{~Gy}$ を照射. また 4 年後の平成 7 年には左臼蓋部に亦で骨転移の進行を認めたためさらに

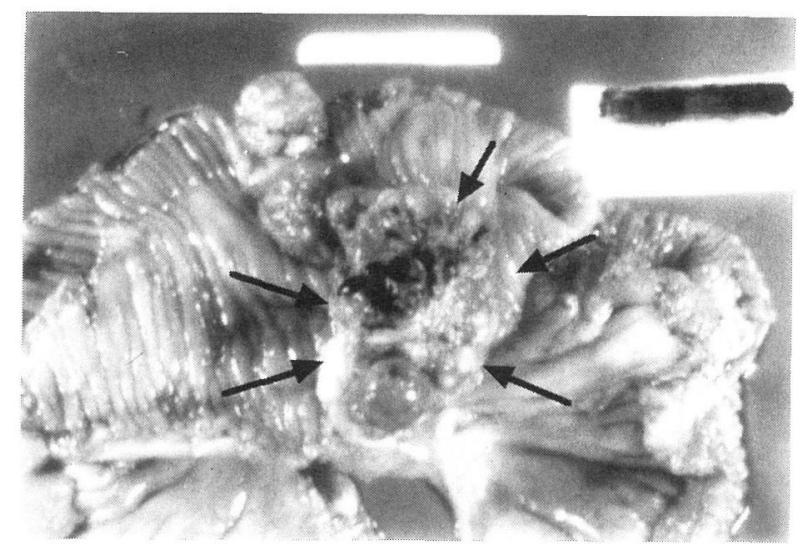

図 3 回腸摘出標本

腫瘍(矢印)の中心部に黒色の色素沈着を認める.

$45 \mathrm{~Gy}$ 追加照射した。これにより同部の疼痛はほぼ消失 した。

当科比忛る治療経過: 初回の放射線治療後約19年間 原発巣の鼻腔には腫瘍の再発は認めなかった. しかし, 平成 9 年 9 月㥧より鼻出血が出現し腫瘍の再発を認めた

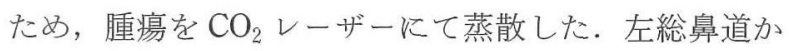
ら下甲介にかけての黒色の色素沈着部分に IFN $\beta$ (300万 単位) の局所注入も計 3 回にわたって併施した. その後, 平成 10 年 5 月頃より再び腫瘍の再発を認めたため手術治 療などを強く勧めるも, 一切の治療を本人に拒否された ため, 経過観察をしていた。しかし, 次第に鼻出血によ

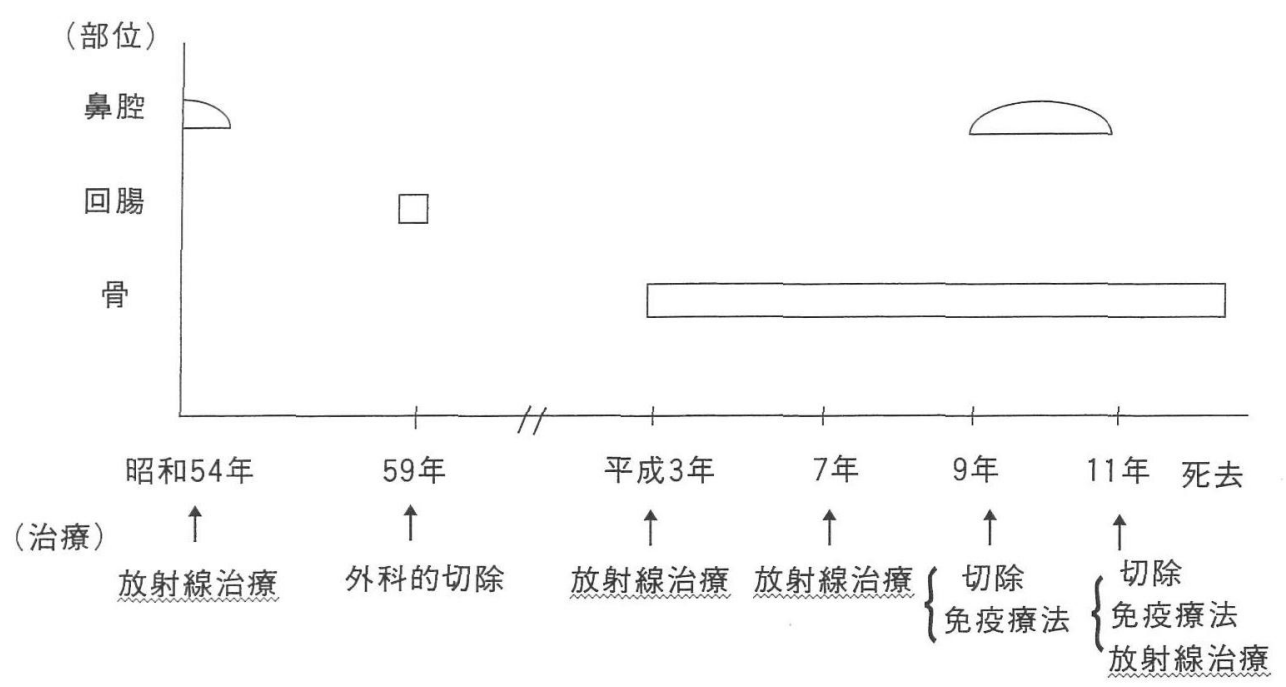

図 2 治療経過 
る貧血の進行を認めたため再度説得の末，翌平成 11 年 1 月から LINAC 45 Gy 执よびIFN $\beta$ (300万単位)の局注 を計 3 回再度施行した。气の結果，鼻腔内に充満してい た暗赤色の易出血性の腫瘍（図 $4 \mathrm{~A}$ ) は著明に縮小した (図 4 B). CT 所見でも腫瘍恃著明に縮小した(図 5 )。

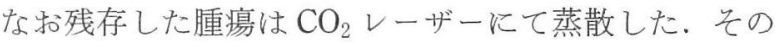

後平成 11 年 4 月に肺炎で死去したものの, 鼻腔内には腫 瘍の再発は認めなかった。な抮，腫瘍マーカーとされる $5 \mathrm{SCD}^{6)}$ は死亡直前は正常範囲内であった。

摘出標本とその際の鼻腔内所見 (平成 9 年) : 鼻中隔前 端部に茎を持つ $2.0 \times 2.5 \mathrm{~cm}$ の暗赤色のポリープ様腫 瘍を認めた（図 6 )。 また鼻腔粘膜にも総鼻道から下甲介,

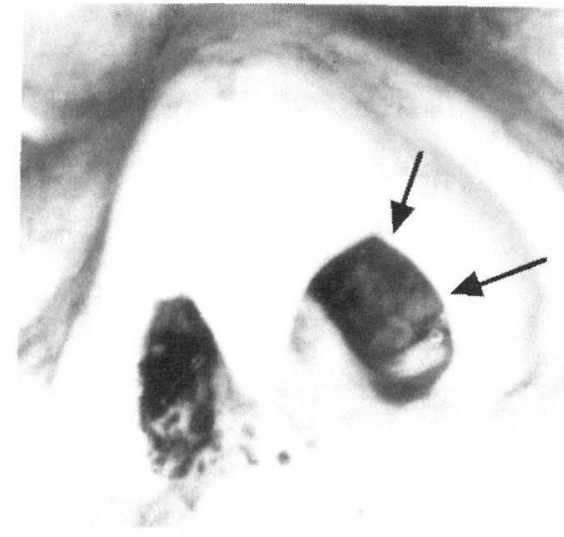

A

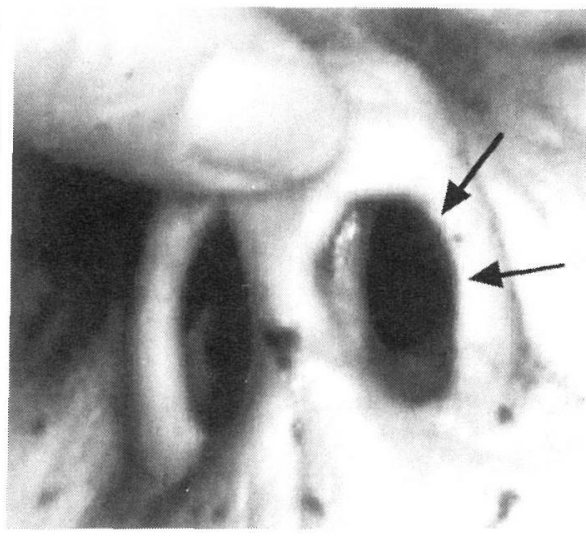

B

図 4 鼻内所見

A : 平成 11 年 1 月左鼻腔に充満した腫瘍を認める (矢印).

B : 同年 3 月治療後, 腫瘍は著明に縮小した(矢印).

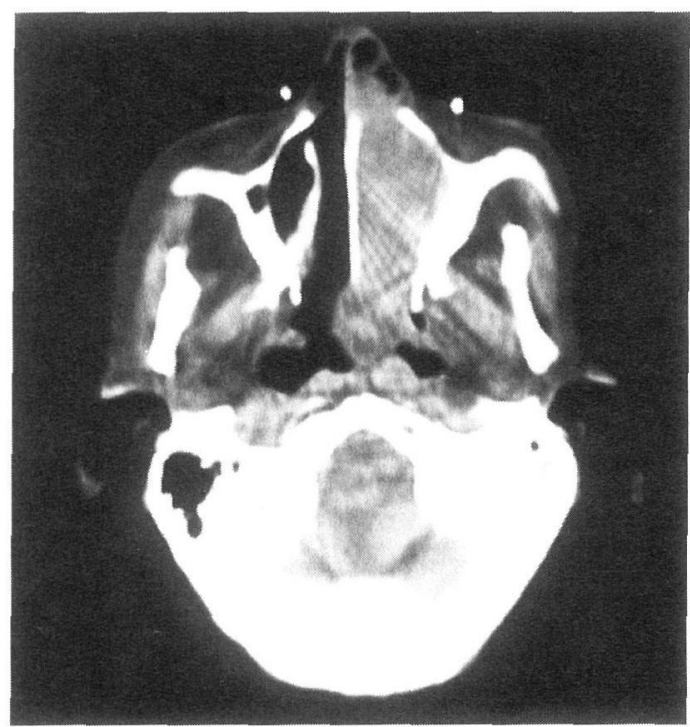

A

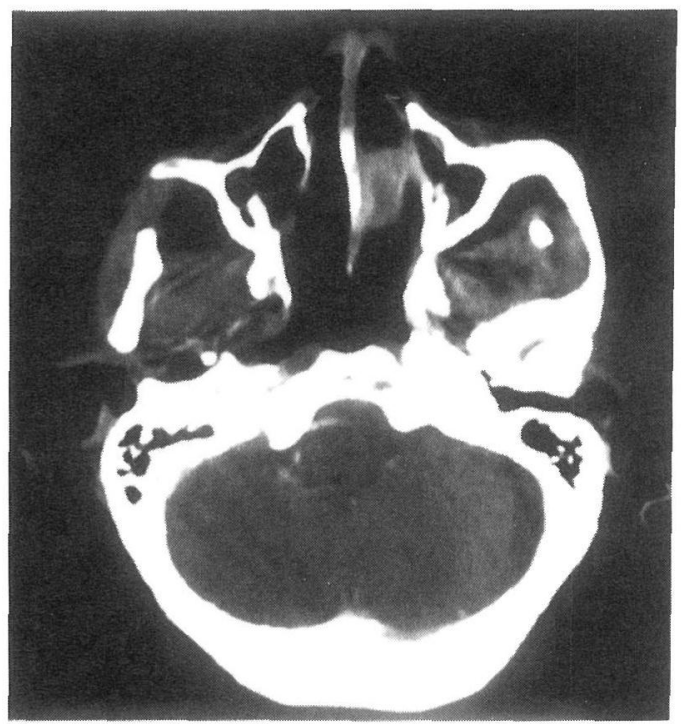

B

図 5 鼻腔 $\mathrm{CT}$ 像

A : 平成11年 1 月左鼻腔に充満した腫痬を認める.

B : 同年 3 月治療後, 腫瘍は著明に縮小した. 


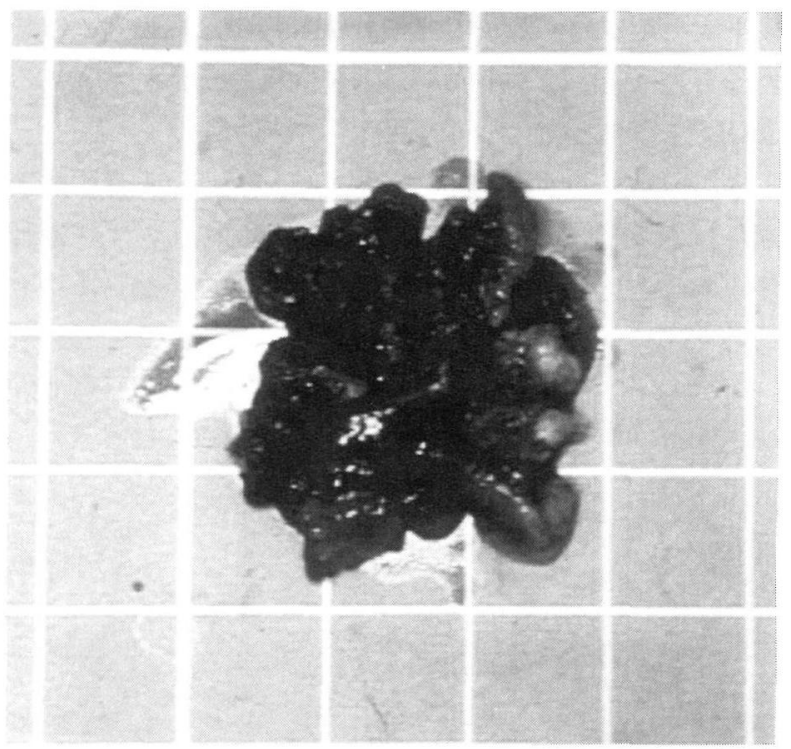

図 6 鼻腔腫痬摘出標本

暗赤色でポリープ様腫瘍を摘出した。

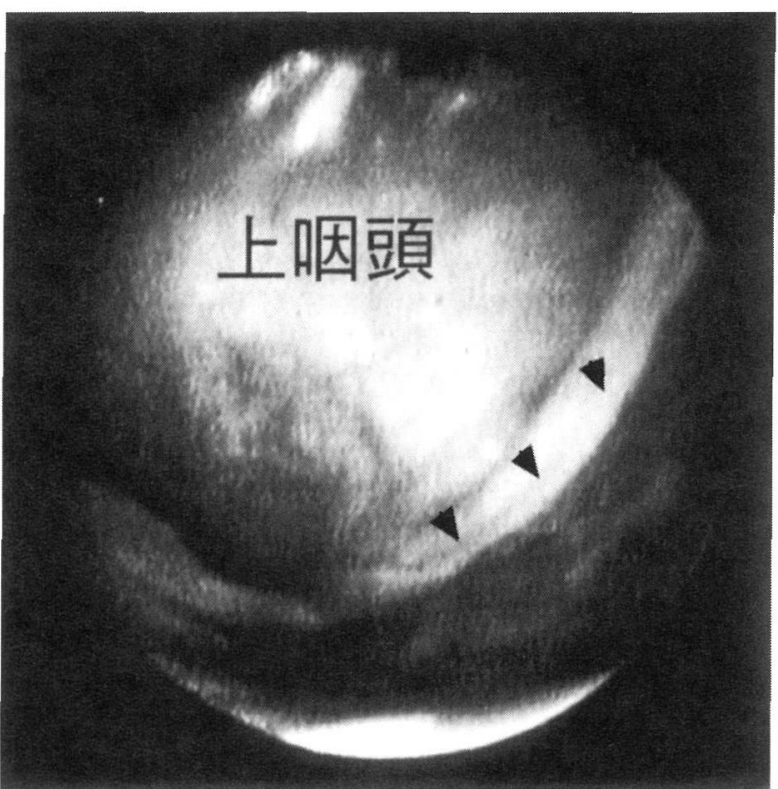

図 7 鼻腔粘膜所見

総鼻道下後方に黒色の色素沈着を認めた(矢尻).

軟口盍上面にわたる本で黒色の色素沈着を認めた(図 7 ).

病理標本 : HE 染色では類円形の細胞で多解形の核を 持つ腫瘍細胞が認められる。一部にメラニン色素も認め

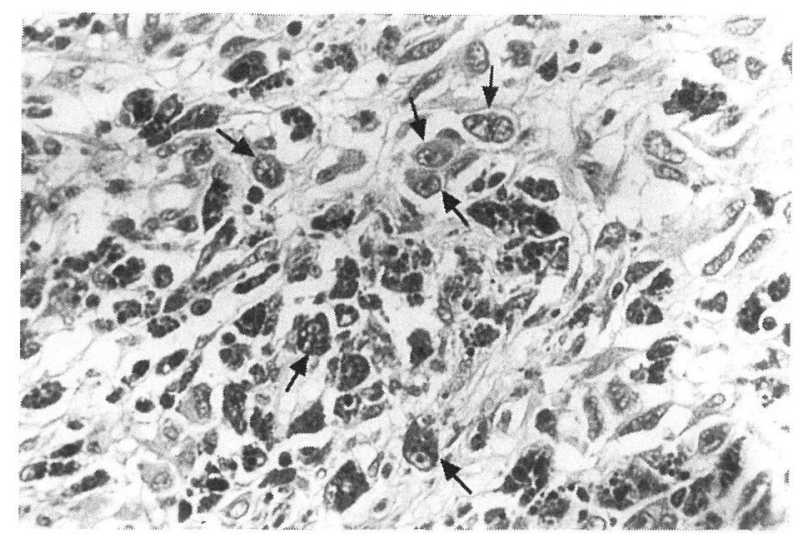

図 $8 \mathrm{HE}$ 染色所見 $(\times 400)$

類円形で多角形の核を持つ腫瘍細胞を認める (矢印). メラニン色素も認める.

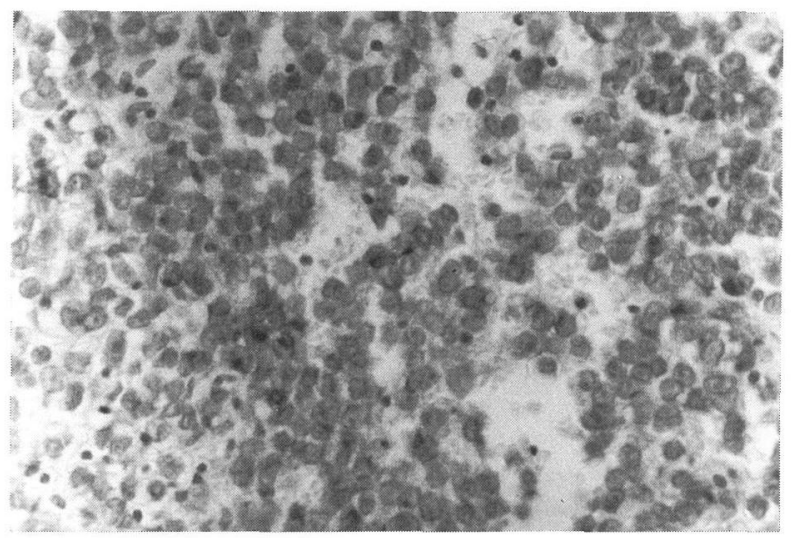

図 9 HMB-45 染色所見 $(\times 400)$

多くの細胞が染まり陽性所見を示した。

る(図 8). 特殊染色では S-100, HMB-45 ともに陽性で 悪性黒色腫の再発と診断された(図 9)。また，アポトー シス関連分子の bcl-2 は陽性であった。

\section{考察}

鼻・副鼻腔悪性黒色腫の頻度は 10 万人に対し 0.3 人 7) で好発年齢は50〜 60歳 ${ }^{8)}$. 性差は一般的にはないが，男 性にやや多いとの報告8)もある. 病態としてはメラニン 生成能を持つ色素細胞から発生する悪性腫瘍之されてい る9．メラニンの含有量により色素性と無色素性に分け られることがある。しかし，両者には明確な境界はなく， 無色素性は診断が難しいという点で予後が悪いとされて いる10) が，病理学的にも予後の面では差はない11). 本症 
例も初期は無色素性と診断されていたが鼻腔内の再発腫 瘍は色素性であった。臨床症状として鼻出血, 鼻閉など があり ${ }^{12)}$, 診断法としては鼻腔内所見, 画像ならびに病 理組織診断などがある. 確定診断は HMB-45などの特 殊染色 ${ }^{13)}$ 飞て行ら。治療としては切除, 化学療法 (DAV，DAVPなど)，放射線治療(大線量少数分割照 射14) や重粒子線治療15) など) や免疫療法(IFN 療法 ${ }^{16)}$, メラノーマ特異抗原療法17)など)があるがいまだに確立 されたものはない，基本的には切除が望ましいが，鼻副 鼻腔領域では十分な安全域がとれないことが多いので, 補助療法として化学療法, 放射線療法などを行うのが一 般的である18199，な拈，本症例では積極的治療に対する 本人の強い拒否により，初期に放射線療法しか行えな かったが，長期にわたり原発巣の再発は起こらなかった。 放射線療法は一般的には無効とされている20)が, 放射 線療法も有効とする報告211 26) もあるので，今後治療方 法の一つとして考虑すべきと思われる.

また予後は一般的には 5 年生存率が $10 \sim 19 \%$ と不良で ある2728). Yanold ら29), Lee ら ${ }^{30)}$ とよると局所再発まで の期間が長いほど予後が良好とされている.しかし，な かには局所再発を繰り返しながらも10年間といら長い経 過をとった症例 31$)$ や本症例のように遠隔転移がありな がらも長期生存し得た例もあり, 一概には予後を判定す るのは困難である. 文献的には腫瘍の厚さと予後との関 連 ${ }^{32)}$ や皮膚悪性黒色腫ではアポトーシス関連分子 bcl-2, bax が陽性なら予後が良好との報告33) もある. 本症例 では bcl-2 陽性であり予後が良好であった一因とも考兄 られる。また，Meyer ${ }^{34)}$ とるる悪性黒色腫は臨床的 に fulminant と nonfulminant 飞分類されるとしている. 免疫学的に tumor-host バランスが保たれていれば予後 が良いとされ3536)，このバランスが崩れると再発を繰り 返し予後は悪くなる．本症例も約19年間は遠隔転移があ るものの比較的緩やかな経過をたどって招り, nonful一 minantな状態であったと考兄られる。しかし，平成 9 年に再発してからは腫瘍は再活性化され, 局所再発を繰 り返しコントロール不良の fulminantな状態となった。 再活性化の原因が何か, また fulminant と nonfulminant との生物学的相違がどこにあるのかは現段階では不明で ある. 今後の悪性黒色腫の治療の進歩のためにも 1 日も 早い解明が待たれる.

\section{まとめ}

1 ) 担癌状態で約 20 年間生存し得た悪性黒色腫の 1 例 を報告した。

2 ) 初期治療としては放射線療法のみで，長期にわた り局所再発を認めなかった。一般的には放射線療法は無 効とされているが治療方法の一つとして考慮するべきで ある。

本論文の要旨は第38回日本鼻科学会(平成11年10月 1 日, 千 葉市)に打いて口演した。

\section{参考文献}

1) 斉藤久樹：鼻副鼻腔悪性黒色腫の臨床. 日本医事新報 $3346: 16 \sim 20,1988$.

2 ) Brandwein MS, Rothstein A, Lawson W, et al : Sinonasal melanoma. Arch Otolaryngol Head Neck Surg $123: 290$ $\sim 296,1997$.

3 ) Eneroth CM and Lundberg C: Mucosal malignant melanomas of the head and neck. Acta Otolaryngol $80: 452$ $\sim 458,1975$.

4 ）川堀真一, 奥田 稔, 小上芳春, 他 : 長い経過をとった鼻 腔覀性黑色腫. 耳鼻臨床 $70: 297 \sim 307,1977$.

5 ）小原宏之, 田中和行, 青木一浩, 他：緩徐な経過を示寸悪 性黒色腫. Skin Cancer 13 : 58 61, 1998.

6）千野一夫, 吉沢公人, 原 弘之, 他: 鼻腔悪性黒色腫のス タンプ蛍光法ならびにガーゼ參出液中 5-S-Cysteinyldopa 測定による術前診断. 耳喉頭頸 $66: 313 \sim 318,1994$.

7 ) 石原和之, 池川修一: 悪性黒色腫の診断と治療. 癌と化学 療法 $12: 1727 \sim 1734,1985$.

8 ）斉藤久樹, 朴沢二郎, 山上美情子: 本邦に扣ける鼻副鼻腔 悪性黑色腫報告例の検討. 日耳鼻 $86: 139 \sim 143,1983$.

9）恒元 博：メラノサイト系腫瘍 一放射線療法一. 現代皮 覤科学大系11(山村雄一, 佐野栄春, 久木田淳, 他編)。66 ８6頁, 中山書店, 東京, 1982 .

10）麻生和雄, 穗積 豊: Amelanotic malignant melanoma 9 一例. 臨皮 $38: 171 \sim 177,1984$.

11) Cochran $\mathrm{AJ}:$ Histology and prognosis in malignant melanoma. J Pathol $97:$ 459 468, 1969.

12）斉藤久樹, 朴沢二郎, 盛 庸, 他: 本邦に扣ける鼻副鼻 腔悪性黒色腫報告例の検討(続報)。日耳鼻 $89: 419 \sim 424$, 1986.

13) Gown A, Vogel A, Hoak D, et al : Monoclonal antibodies specific for melanocytic tumors distinguish subpopulations of melanocytes. Am J Path $123:$ 195 203, 1986.

14）西村哲夫, 手島 威: 頭頸部悪性黒色腫の放射線治療. 癌 の臨床 $38: 636 \sim 642,1992$. 
15）山崎たくみ, 吉原俊雄, 石井哲夫 : 上咽頭原発悪性黒色腫 の 1 例. 耳鼻 $44: 786 \sim 790,1998$.

16）假谷 伸, 赤木博文, 結縁晃治, 他 : 鼻副鼻腔悪性黒色腫 の 2 症例. 耳喉頭頸 $68: 598 \sim 602,1996$.

17）河上 裕：メラノ一マ腫瘍抗原と細胞治療. 血液・腫瘍科 $38: 1 \sim 8,1999$.

18）肥後隆三郎, 菅沢 正, 水野正浩, 他 : 鼻 - 副鼻腔悪性黒 色腫 5 例. 耳鼻 $38: 762 \sim 767,1992$.

19) Poissonnet G, Castillo L, Dassonville $O$, et al : Malignant nasosinusal melanomas. Rev Laryngol Otol Rhinol 118 : 155 161, 1997.

20) Lund VJ, Howard DJ, Harding L, et al : Management options and survival in malignant melanoma of the sinonasal mucosa. Laryngoscope $109: 208 \sim 211,1999$.

21）森 俊二：放射線療法. 皮膚科 Mook No. 18 (今村貞夫, 小川秀興, 三嶋 豊, 他編). 195 199頁, 金原出版, 東 京, 1992 .

22）高畑喜延, 佃守, 大石公直, 他 : 鼻 - 副鼻腔悪性黒色 腫 5 例. 耳鼻 $29: 796 \sim 805,1983$.

23）酒井俊一, 伊東真人, 兵 行和, 他 : 頭頸部粘膜に発生し た悪性黒色腫30例. 耳鼻臨床 $78 ： 2799 \sim 2812,1985$.

24) Gilligan D and Slevin NJ : Radical radiotherapy for 28 cases of mucosal melanoma in the nasal cavity and sinuses. Br J Radiol 64 : 1147 1150, 1991.

25）飯田智二郎, 柴 徹, 小野誠治, 他 : Stereotactic Radiosurgery が著効した篩骨洞原発悪性黒色腫の 1 例. Nippon Acta Radiologica 58 : 775, 1998.

26) Myers JN : Value of neck dissection in the treatment of patient with intermedite-thickness cutaneous malignant melanoma of the head and neck. Arch Otolaryngol Head Neck Surg $125: 110 \sim 117,1999$.

27) Eneroth $\mathrm{CM}$ and Lundberg $\mathrm{C}$ : Mucosal malignant melanomas of the head and neck with special reference to cases having a prolonged clinical course. Acta Otolaryngol $80: 452 \sim 458,1975$.

28) Hoyt DJ, Jordan T and Fisher SR : Mucosal melanoma of the head and neck. Arch Otolaryngol Head Neck Surg $115:$ 1096 1099, 1989.

29) Yanold JR and Cochrane JPS : Malignant melanoma; significance of disease-free interval. $\mathrm{Br} \mathrm{J}$ Radiol 53 : 1068 1070, 1980 .

30) Lee SP, Shimizu KT and Tran LM : Mucasal melanoma of the head and neck ; the impact of local control on survival. Laryngoscope $104: 121 \sim 126,1994$.

31) Wright JL and Heenan PJ : Prolonged survaival in malignant melanoma of the nose. J Laryngol Otol $88: 77 \sim 84$, 1974.

32) Trapp TK, Fu YS and Calcatera TC : Melanoma of the nasal and paranasal sinus mucosa. Arch Otolaryngol Head Neck Surg 113 : 1086 1089, 1987.

33）川口とし子：皮膚悪性黒色腫の原発巣拈よび転移巣に打け るアポトーシス関連分子の発現について. 横浜医学 49 : 989 995, 1998.

34) Meyer HW : Appraisal of progress in surgical therapy. Surgery $41: 335,1957$.

35) Lund V : Malignant melanoma of the nasal cavity and paranasal sinuses. J Laryngol Otol $96: 347 \sim 355,1982$.

36) Crowley NJ and Seigler HF : Relationship between disease-free interval and survival in patients with recurrent melanoma. Arch Surg 127 : 1303 1308, 1992.

$$
\left.\begin{array}{l}
\text { 原稿受付 : 平成 } 12 \text { 年 } 5 \text { 月 } 25 \text { 日 } \\
\text { 原稿採択 : 平成 } 12 \text { 年 } 7 \text { 月 } 5 \text { 日 } \\
\text { 別刷請求先 : 田浦晶子 } \\
\text { 干7 } 606-8507 \text { 京都市左京区聖護院川原町 } 54 \\
\text { 京都大学大学院医学研究科 感覚運動系病態学講座 } \\
\text { 耳鼻咽喉科・頭頸部外科学 }
\end{array}\right)
$$

